\title{
Influence of contrasting environments on seed composition of two quinoa genotypes: nutritional and functional properties
}

\author{
Margarita Miranda ${ }^{1}$, Antonio Vega-Gálvez ${ }^{1}$, Enrique A. Martínez ${ }^{2}$, Jéssica López ${ }^{3}$, Rosa Marín ${ }^{1}$, \\ Mario Aranda ${ }^{4}$, and Francisco Fuentes ${ }^{5^{*}}$
}

\begin{abstract}
Quinoa (Chenopodium quinoa Willd.) in Chile represents a source of germplasm with high nutritional value. However, there is little information available related to quinoa seed quality grown under contrasting environments. In this study we evaluated the changes on seed composition of seeds of two lowland/coastal quinoa genotypes grown under arid (Vicuña) and cold-temperate (Temuco) conditions in Chile. Results showed that in the case of 'Regalona Baer' and 'Villarrica' genotypes the arid location (with irrigation) led to a significant increase $(P<0.05)$ in grain yield $\left(4.2\right.$ and $5.1 \mathrm{t}$ ha ${ }^{-1}$, respectively), soluble dietary fiber $\left(16.8 \pm 0.4\right.$ and $28.9 \pm 2.1 \mathrm{~g} \mathrm{~kg}^{-1} \mathrm{DM}$, respectively), vitamin $\mathrm{B}_{3}(2.44 \pm 0.005$ and 2.26 $\pm 0.04 \mathrm{mg} 100 \mathrm{~g}^{-1} \mathrm{DM}$, respectively), saponins (3.22 $\pm 0.38 \mathrm{mg} 100 \mathrm{~g}^{-1} \mathrm{DM}$, 'Regalona Baer'), phenolic compounds (19.2 \pm 5.48 and $31.92 \pm 1.14 \mathrm{mg}$ gallic acid $100 \mathrm{~g}^{-1} \mathrm{DM}$, respectively) and components of proximate analysis, except protein content. The cold-temperate climate (rainfed) affected positively seed size (2.22 $\pm 0.17 \mathrm{~mm}$ 'Villarrica') and 1000 seed weight $\left(3.08 \pm 0.08\right.$ and $3.29 \pm 0.08 \mathrm{~g}$, respectively), as well as insoluble dietary fiber content $\left(112.3 \pm 23.8 \mathrm{~g} \mathrm{~kg}^{-1} \mathrm{DM}\right.$ 'Regalona Baer'). Furthermore, vitamin C was higher in 'Regalona Baer' genotype at arid locality (31.22 $\pm 4.2 \mathrm{mg} 100$ $\left.\mathrm{g}^{-1} \mathrm{DM}\right)$, but much higher content was registered in 'Villarrica' genotype at cold-temperate climate $(49.3 \pm 5.36 \mathrm{mg} 100$ $\left.\mathrm{g}^{-1} \mathrm{DM}\right)$. The environment-induced relationship among variables and genotypes was consistent with principal component analysis (PCA). The arid region of Vicuña in Chile represents a potential area for quinoa cultivation for lowland/coastal quinoa genotypes, whose nutritional and functional features were affected positively, due to the much more stressing climatic conditions.
\end{abstract}

Key words: Chenopodium quinoa, climate stress, antioxidant activity, phenolic compounds, protein, mineral content.

\section{INTRODUCTION}

Chenopodium quinoa Willd., commonly known as quinoa, is a native crop of South America, which has been traditionally used as a staple food source by ancestral populations along the Andes region (Fuentes et al., 2012). Over the past decade, quinoa has gained worldwide attention because of its nutritional value and functional features (Vega-Gálvez et al., 2010), as well as its ability to grow in a wide range of climates and soils, showing a good potential as a grain crop even in new areas outside of its native region, such as cold and subtropical regions in Europe and Asia, respectively (Bhargava et al., 2007). So far, in South American countries like Bolivia, Peru,

${ }^{1}$ Universidad de La Serena, Departamento de Ingeniería en Alimentos. Av. Raúl Bitrán s/n. Casilla 599, La Serena, Chile.

${ }^{2}$ Centro de Estudios Avanzados en Zonas Áridas (CEAZA), Av. Raúl Bitrán s/n, Casilla 599, La Serena, Chile.

${ }^{3}$ Universidad de Santiago de Chile (USACH), Facultad Tecnológica, Obispo Umaña 050, Santiago, Chile.

${ }^{4}$ Universidad de Concepción, Facultad de Farmacia, Casilla 237, Concepción, Chile.

${ }^{5}$ Universidad Arturo Prat, Facultad de Recursos Naturales Renovables, Av. Arturo Prat 2120, Iquique, Chile.

*Corresponding author (francfue@unap.cl)

Received: 18 September 2012.

Accepted: 12 February 2013.

doi:10.4067/S0718-58392013000200004
Ecuador, and Chile, there has been an expansion of its production and export market, as a consequence of an increased use of quinoa seeds in the world consumption of whole and also processed grains (Miranda et al., 2010). Thus, the nutritional value of quinoa has been basically recognized for its high-quality protein, particularly rich in essential amino acids, good source of minerals $(\mathrm{Ca}, \mathrm{P}$, and $\mathrm{Mg})$, dietary fiber, antioxidant compounds such as carotenoids, flavonoids (e.g. kaempferol and quercetin), vitamin $\mathrm{C}$, riboflavin, thiamine, folic acid, $\alpha$ - and $\gamma$-tocopherol, and carbohydrates, which has been reported to have lower glycemic index and general better overall high nutritional quality compared to that of cereals such as corn (Zea mays L.), oat (Avena sativa L.), wheat (Triticum aestivum L.), and rice (Oryza sativa L.) (Ruales and Nair, 1993; Repo-Carrasco et al., 2003). Even, the Food and Agriculture Organization (FAO) has recently decided to name 2013 as the international year of quinoa crop due to its role in achieving food and nutritional security and and its usefulness for poverty eradication (United Nations, 2011).

The most austral, also ancient source of quinoa genotypes is found in Chile (Fuentes et al., 2012). This germplasm has been transmitted from the highlands by pre-Incas cultures of Peru and Bolivia $\left(12^{\circ} \mathrm{S}\right.$ lat $)$ to the cold-temperate climates of southern Chile $\left(40^{\circ} \mathrm{S}\right.$ lat) in a slow process estimated to have occurred through 3000 
yr. Thus, during the last $400 \mathrm{yr}$, due to colonization, cultural changes in agricultural practices, and also due to climate change towards drier conditions; some regions of Chile -like the arid Region of Coquimbo at $30^{\circ} \mathrm{S}$ lat- lost the germplasm, as well as the ancestral cultural inheritance held by the remnants of such ancestral people. This process has been recently described for small-scale agriculture in Chile with traces of effects even on the genetic diversity of quinoa cultivars (Fuentes et al., 2012). In spite of the above, there have been efforts aiming to re-introduce seeds from other latitudes (Martínez et al., 2009).

The recovery process of quinoa seed genotypes from small-scale farmers of southern Chile is very important due to such unique germplasm, well adapted to a photoperiod of long-days, an important feature for countries of northern latitudes or for countries where there is a need of highly nutritive crops, well adapted to stressing environmental conditions (Martínez et al., 2009). In this context, recent studies on local ecotypes of quinoa in Chile have reported a wide genetic diversity (Fuentes et al., 2012), which have been related to the variation in nutrient content (Miranda et al., 2012). However, the interaction of environmental factors affecting the nutritional value of quinoa grain stresses the importance to understand the bioavailability of its composition.

The aim of the present study was to evaluate changes in the nutritional and functional properties in seeds of two lowland/coastal quinoa genotypes ('Regalona Baer' and 'Villarrica') grown under arid (with irrigation) and coldtemperate (rainfed) conditions in Chile.

\section{MATERIAL AND METHODS}

\section{Trial locations, environment and soil conditions}

The two locations with contrasting environment were (a) Temuco, a cold-temperate climate of southern Chile ( $38^{\circ} 40^{\prime} \mathrm{S}, 72^{\circ} 30^{\prime} \mathrm{W}, 166 \mathrm{~m}$ a.s.1.), and (b) Vicuña, an arid locality in the mid north $\left(30^{\circ} 2^{\prime} \mathrm{S}, 70^{\circ} 42^{\prime} \mathrm{W}, 657 \mathrm{~m}\right.$ a.s.l.). Temuco locality is typically characterized by lower mean temperatures and higher relative humidity during experimental cultivation period from October to April 2009/2010 and 2010/2011 (Table 1). The rainfall pattern at the arid Vicuña locality during both cropping seasons was diametrically opposed to that observed in Temuco. The mean accumulated rainfall during experimental cultivation period at Temuco locality reached $367.7 \mathrm{~mm}$, against $1.9 \mathrm{~mm}$ registered at the arid Vicuña locality (Table 1). The soil analysis revealed that arid soil in Vicuña was sandier, more saline, and lower in organic matter than the soil of the cold-temperate locality. In addition, Temuco plot soil had higher water retention and was richer in $\mathrm{P}$ and $\mathrm{K}$ than the Vicuña plot soil. Soil parameters were analyzed in triplicate by AGROLAB S.A. according to Karyotis et al. (2003). The relevant soil parameters of each location are shown in Table 2.
Table 1. Weather conditions during quinoa development in the cropping seasons at Temuco and Vicuña localities ${ }^{1}$.

\begin{tabular}{|c|c|c|c|c|c|c|}
\hline \multirow[b]{2}{*}{ Month } & \multicolumn{2}{|c|}{ Mean temperature } & \multicolumn{2}{|c|}{ Humidity } & \multicolumn{2}{|c|}{ Rainfall } \\
\hline & Temuco & Vicuña & Temuco & Vicuña & Temuco & Vicuña \\
\hline \multicolumn{7}{|c|}{$\longrightarrow{ }^{\circ} \mathrm{C}$} \\
\hline October & 10.4 & 16.2 & 77.5 & 55.7 & 81.5 & - \\
\hline November & 10.5 & 17.7 & 77.1 & 49.7 & 91.5 & - \\
\hline December & 13.6 & 19.7 & 77.8 & 57.2 & 57.1 & - \\
\hline January & 15.1 & 20.1 & 75.4 & 63.2 & 33.8 & 2.0 \\
\hline February & 14.5 & 20.3 & 74.8 & 65.7 & 70.1 & - \\
\hline March & 14.5 & 17.4 & 82.1 & 69.6 & 46.5 & - \\
\hline April & 10.8 & 15.0 & 81.4 & 67.7 & 18.5 & - \\
\hline Mean & $12.8 \pm 2.1$ & $18.0 \pm 2.0$ & $78.0 \pm 2.8$ & $61.3 \pm 7.3$ & $57 \pm 26.1$ & 0.3 \\
\hline \multicolumn{7}{|l|}{ 2010-2011 } \\
\hline October & 10.7 & 14.6 & 79.2 & 63.4 & 35.6 & - \\
\hline November & 12.2 & 16.8 & 79.9 & 63.8 & 46.2 & - \\
\hline December & 13.5 & 17.5 & 77.2 & 58.7 & 37.6 & - \\
\hline Januar & 16.4 & 19.5 & 70.9 & 63.4 & 43.7 & - \\
\hline Febrt & 16.3 & 19.6 & 71.6 & 65.8 & 29.0 & - \\
\hline Mar & 13 & 17 & 75.6 & 66.9 & 39.4 & - \\
\hline Apri & 11.3 & 15.2 & 82.9 & 72.7 & 104.9 & 1.8 \\
\hline Mean & $13.5 \pm 2.3$ & $17.2 \pm 1.9$ & $76.8 \pm 4.4$ & $65.0 \pm 4.3$ & $48 \pm 25.7$ & 0.3 \\
\hline
\end{tabular}

${ }^{1}$ Climatic data were obtained from weather stations of Temuco located at $38^{\circ} 44^{\prime} \mathrm{S}, 72^{\circ} 36^{\prime} \mathrm{W}, 110 \mathrm{~m}$ a.s.l.; and Vicuña located at $30^{\circ} 2^{\prime} \mathrm{S}, 70^{\circ} 42^{\prime} \mathrm{W}$, $657 \mathrm{~m}$ a.s.1.

Table 2. General soil characterization of experimental plots at Temuco and Vicuña localities $(0-20 \mathrm{~cm})$.

\begin{tabular}{|c|c|c|}
\hline Soil parameters & Temuco & Vicuña \\
\hline \multicolumn{3}{|l|}{ Fertility } \\
\hline pH suspension in $\mathrm{H}_{2} \mathrm{O}(1: 2.5)$ & $5.9 \pm 0.30$ & $6.8 \pm 0.21$ \\
\hline Organic matter, $\%$ & $9.7 \pm 1.11$ & $2.4 \pm 0.40$ \\
\hline Available $\mathrm{N}, \mathrm{mg} \mathrm{kg}^{-1}$ & $61.0 \pm 33.30$ & $109.7 \pm 78.68$ \\
\hline Available $\mathrm{P}, \mathrm{mg} \mathrm{kg}^{-1}$ & $44.0 \pm 14.99$ & $17.3 \pm 7.09$ \\
\hline Available $\mathrm{K}, \mathrm{mg} \mathrm{kg}^{-1}$ & $700.8 \pm 80.54$ & $246.3 \pm 63.61$ \\
\hline \multicolumn{3}{|l|}{ Available micronutrients } \\
\hline $\mathrm{Zn}, \mathrm{mg} \mathrm{kg}^{-1}$ & $5.4 \pm 1.70$ & $10.7 \pm 1.80$ \\
\hline $\mathrm{Mn}, \mathrm{mg} \mathrm{kg}^{-1}$ & $138.5 \pm 34.03$ & $26.1 \pm 6.59$ \\
\hline $\mathrm{Fe}, \mathrm{mg} \mathrm{kg}^{-1}$ & $103.9 \pm 9.85$ & $17.3 \pm 3.49$ \\
\hline $\mathrm{Cu}, \mathrm{mg} \mathrm{kg}^{-1}$ & $4.1 \pm 0.78$ & $16.4 \pm 2.45$ \\
\hline $\mathrm{B}, \mathrm{mg} \mathrm{kg}^{-1}$ & $1.3 \pm 0.26$ & $4.3 \pm 0.46$ \\
\hline \multicolumn{3}{|l|}{ Exchangeable cations } \\
\hline $\mathrm{Ca}, \mathrm{cmol} \mathrm{kg}^{-1}$ & $13.4 \pm 2.92$ & $12.8 \pm 1.39$ \\
\hline $\mathrm{Mg}, \mathrm{cmol} \mathrm{kg}^{-1}$ & $2.4 \pm 0.74$ & $2.9 \pm 0.46$ \\
\hline $\mathrm{Na}, \mathrm{cmol} \mathrm{kg}^{-1}$ & $0.16 \pm 0.08$ & $0.49 \pm 0.07$ \\
\hline $\mathrm{K}, \mathrm{cmol} \mathrm{kg}^{-1}$ & $1.8 \pm 0.21$ & $0.63 \pm 0.17$ \\
\hline $\mathrm{CEC}^{1}, \mathrm{cmol} \mathrm{kg}^{-1}$ & $39.2 \pm 3.16$ & $16.9 \pm 1.93$ \\
\hline \multicolumn{3}{|l|}{ Salinity } \\
\hline $\mathrm{pH}$ & $6.6 \pm 0.58$ & $7.8 \pm 0.06$ \\
\hline Electrical conductivity, $\mathrm{dS} \mathrm{m}^{-1}$ & $0.63 \pm 0.45$ & $3.13 \pm 1.31$ \\
\hline SAR (sodium adsorption ratio) & $0.45 \pm 0.17$ & $1.27 \pm 0.06$ \\
\hline \multicolumn{3}{|l|}{ Texture } \\
\hline Sand $(2.0-0.05), \%$ & $24.5 \pm 2.52$ & $40.0 \pm 6.93$ \\
\hline Silt $(0.05-0.002 \mathrm{~mm}), \%$ & $42.0 \pm 2.83$ & $32.0 \pm 1.73$ \\
\hline Clay $(<0.002 \mathrm{~mm}), \%$ & $33.5 \pm 1.00$ & $26.7 \pm 4.62$ \\
\hline Texture class & Clay loam & Loam \\
\hline \multicolumn{3}{|l|}{ Soluble cations and anions } \\
\hline $\mathrm{Ca}, \mathrm{mg} \mathrm{L}^{-1}$ & $67.5 \pm 46.83$ & $380.0 \pm 174.86$ \\
\hline $\mathrm{Mg}, \mathrm{mg} \mathrm{L}^{-1}$ & $10.5 \pm 6.81$ & $93.0 \pm 41.07$ \\
\hline $\mathrm{K}, \mathrm{mg} \mathrm{L}^{-1}$ & $23.5 \pm 10.63$ & $28.0 \pm 13.23$ \\
\hline $\mathrm{Na}, \mathrm{mg} \mathrm{L}^{-1}$ & $15.3 \pm 10.94$ & $105.0 \pm 20.30$ \\
\hline $\mathrm{Cl}, \mathrm{mg} \mathrm{L}^{-1}$ & $11.5 \pm 0.58$ & $119.3 \pm 38.76$ \\
\hline $\mathrm{SO}_{4}, \mathrm{mg} \mathrm{L}^{-1}$ & $14.0 \pm 6.16$ & $800.0 \pm 168.57$ \\
\hline $\mathrm{HCO}_{3}, \mathrm{mg} \mathrm{L}^{-1}$ & $51.5 \pm 26.13$ & $150.7 \pm 19.86$ \\
\hline Soil water retention, $\%$ from saturation & $54.3 \pm 5.74$ & $34.3 \pm 4.04$ \\
\hline
\end{tabular}

All data are means \pm SD of three replicates. CEC: cation exchange capacity. 


\section{Plant material and experimental design of field trials}

Seeds of two lowland/coastal genotypes of quinoa, cultivated traditionally in cold-temperate southern Chile ( $39^{\circ} \mathrm{S}$ lat) were used in the present study. Genotypes consisted of the commercial var. Regalona Baer, officially accessed from the Protected Variety Records of Chile (SAG, 2012); and the local var. Villarrica, selected by cultural practices of small-scale farmers, producing also at the same latitude in southern Chile. The plot trials were arranged in six parcels of $450 \mathrm{~m}^{2}$, randomly distributed on a surface of $3000 \mathrm{~m}^{2}$, with three replicates per genotype in each environment. Sowing density was $12 \mathrm{~kg} \mathrm{ha}^{-1}$ in Temuco and $4 \mathrm{~kg} \mathrm{ha}^{-1}$ in Vicuña, both with $0.4 \mathrm{~m}$ between rows at $2 \mathrm{~cm}$ depth. When plants emerged, conventional pest, disease and weed control was undertaken as and when required. The crop was conducted in Temuco region under rainfed conditions, whereas in Vicuña the irrigation was performed once every $10 \mathrm{~d}$ at $3 / 4$ of field capacity. Thus, in each site there were not any agronomic, watering, or nutritional constraints for crop development. Plant and seed dry biomass (g) were measured at the end of the harvest season for 15 plants of each genotype, randomly taken from each parcel. Harvest index (\%) was estimated as the ratio of seeds to whole plant dry-biomass. A composite seed sample from each replicate was used to estimate seed diameter and 1000 seed weight parameters.

\section{Experimental analytical procedures}

Grain samples were collected from each replicate, in a composite sample plot, during the harvest season of 2010 in Temuco and 2011 in Vicuña, when the grain reached physiological ripeness ( $<14 \%$ humidity). Seeds samples were analyzed without a dehusking treatment and were only visually inspected to discard any contaminant particles or impurities. The dried samples were ground using a grinder (MC0360, UFESA, Zhejiang, China) to obtain a fine powder to perform the analysis. All chemicalanalytical determinations were done in triplicate.

Moisture content was determined by AOAC method nr 934.06 (AOAC, 1995). Crude protein content was determined using the Kjeldahl method with a conversion factor of 6.25 (AOAC $\mathrm{nr}$ 960.52). Lipid content was analyzed gravimetrically following Soxhlet extraction (AOAC nr 960.39). Crude fiber was estimated by acid/ alkaline hydrolysis of insoluble residues (AOAC nr 962.09). Crude ash content was estimated by incineration in a muffle furnace at $550{ }^{\circ} \mathrm{C}$ (AOAC nr 923.03). All methodologies followed the recommendations of the Association of Official Analytical Chemists (AOAC, 1995). pH was measured using an microcomputer pH-vision 246072 (EXTECH Instruments, Waltham, Massachusetts, USA) (AOAC nr 981.12), and the level of titrimetric acidity was expressed as sulfuric acid (AOAC nr 925.53). Water activity $\left(\mathrm{a}_{\mathrm{w}}\right)$ was measured at $25{ }^{\circ} \mathrm{C}$ by means of a water activity meter (model TH500, Novasina, Pfäffikon, Lachen, Switzerland). Total dietary (TDF), soluble (SDF) and insoluble (IDF) fibers were determined by the gravimetric-enzymatic method (AOAC nr 985 .29) by using a TDF Assay Kit (TDF100A, Sigma-Aldrich, St. Louis, Missouri, USA). TDF, IDF, and SDF were expressed in $\mathrm{g} \mathrm{kg}^{-1} \mathrm{DM}$. Carbohydrates (sucrose, glucose, and raffinose) were determined by high performance thin-layer chromatography (HPTLC) according to Patzsch et al. (1988), with some modifications described by Aranda et al. (2005). Sugar content was expressed in $\mathrm{g} \mathrm{kg}^{-1} \mathrm{DM}$. Mineral elements ( $\mathrm{Na}, \mathrm{K}, \mathrm{Ca}, \mathrm{Mg}, \mathrm{Cu}, \mathrm{Mn}, \mathrm{Zn}, \mathrm{P}$, and $\mathrm{Fe}$ ) were measured by atomic absorption spectrophotometer (AAS; SpectrAA-220, Shimadzu Instruments, Kyoto, Japan) after digestion with a $\mathrm{H}_{2} \mathrm{SO}_{4}, \mathrm{HNO}_{3}$, and $\mathrm{HClO}_{4}$ mixture. The $\mathrm{P}$ content was estimated using a phospho-vanadium molybdenum complex at $466 \mathrm{~nm}$ (Spectrophotometer UV-120-02, Shimadzu Instruments) as described by Miranda et al. (2010). The minerals were expressed in $\mathrm{mg}$ $100 \mathrm{~g}^{-1}$ DM. Determinations of vitamin $\mathrm{B}_{1}$ (thiamine), $\mathrm{B}_{2}$ (riboflavin), and $\mathrm{B}_{3}$ (niacin) were performed by acid and enzymatic hydrolysis, and separated with different HPLC columns, in the appropriate mobile phases, and detections performed at the respective wave lengths according to AOAC nr 942.23, 970.65, and 961.1417 (AOAC, 1995), respectively. The vitamin content was expressed in $\mathrm{mg}$ $100 \mathrm{~g}^{-1} \mathrm{DM}$. Determination of vitamin $\mathrm{C}$ was performed by certification of NBS (N-bromosuccinimide) according to Barakat et al. (1955) with modifications (Miranda et al., 2012). The content of vitamin $C$ was expressed in $\mathrm{mg}$ vitamin $\mathrm{C} 100 \mathrm{~g}^{-1} \mathrm{DM}$. Saponins were analyzed based on the reverse-phase HPLC procedure described by San Martín and Briones (2000), with some modifications (Miranda et al., 2012). Saponins content was expressed in $\mathrm{mg} 100 \mathrm{~g}^{-1} \mathrm{DM}$. Total phenolic content (TPC) was determined colorimetrically using Folin-Ciocalteau reagent (FC) according to Chuah et al. (2008). TPC content was expressed in $\mathrm{mg}$ gallic acid (GA) $100 \mathrm{~g}^{-1}$ DM. Free radical scavenging activity of the samples was determined using the 2,2,-diphenyl-2-picryl-hydrazyl (DPPH) method according to Miranda et al. (2010). The DPPH radicals scavenging rate of sample was calculated as percent inhibition relative to control.

\section{Statistical analysis}

The ANOVA of data set was performed using Statgraphics ${ }^{\circledR}$ Plus 5 (Statistical Graphics Corp., Herndon, Virginia, USA) software. Significance testing was carried out using Fisher's least significant difference (LSD) test $(P<0.05)$ for localities and each variable assessed in the two genotypes at two environments. Principal component analysis (PCA) (Hair et al., 1992) of an environment/ genotype $\times$ trait matrix, containing standardized trait data, was analyzed through a biplot constructed by plotting the symmetrically scaled principal component 1 (PC1) scores against the principal component 2 (PC2) scores by using InfoStat ${ }^{(I n f o s t a t, ~ 2008) ~ s t a t i s t i c a l ~ s o f t w a r e . ~}$ 


\section{RESULTS AND DISCUSSION}

In general, the two contrasting environments affected the seed yield components in both quinoa genotypes. Thus, grain yields obtained per plant at the arid Vicuña locality had a mean harvest index of 0.35 and 0.38 for 'Regalona Baer' and 'Villarrica', respectively. This allowed estimating a production of $6.0 \mathrm{tha}^{-1}$ for both genotypes at Vicuña locality; whereas grain yields at the cold-temperate condition of Temuco were $1.8 \pm 1.78 \mathrm{tha}^{-1}$ for 'Regalona Baer' and $0.9 \pm 0.56 \mathrm{t} \mathrm{ha}^{-1}$ for 'Villarrica', representing a significant increase $(\mathrm{P}<0.05)$ in grain yield of 4.2 and 5.1 $\mathrm{t} \mathrm{ha}^{-1}$, respectively. Likewise, it was possible to observe in Villarrica genotype a significant decrease $(\mathrm{P}<0.05)$ in seed diameter and 1000 seed weight values, when it was grown at the arid locality of Vicuña respect to coldtemperate climate, meanwhile Regalona Baer genotype only showed a decrease $(\mathrm{P}<0.05)$ for 1000 seed weight value (Table 3). Thus, grain yields in Vicuña were high enough to be sure that water availability was not a limiting condition for both genotypes, but affecting however, seed size and weight components. Then, it can be perfectly possible that southern genotypes, from cold-temperate environments (typically from $39^{\circ} \mathrm{S}$ lat) could be sown at much northern latitudes $\left(30^{\circ} \mathrm{S}\right.$ lat), without restrictions of different photoperiods and given a minimum amount of water by irrigation. Similar results have been also obtained previously for two lowland/coastal quinoas from central Chile (from $34^{\circ} \mathrm{S}$ lat) in the hyperarid Coquimbo region (Martínez et al., 2009). Consequently, most of the nutritional and functional differences between the Temuco seeds and those harvested at the arid Vicuña locality can be attributed to the contrasting environment between localities, including the different soil properties. Such nutritional and functional differences and similarities are described below.

Seed moisture content of the two quinoa genotypes grown at Temuco and Vicuña localities showed significant

Table 3. Seed traits and chemical composition of two quinoa genotypes grown at Temuco and Vicuña localities.

\begin{tabular}{|c|c|c|c|c|}
\hline \multirow[b]{2}{*}{ Component } & \multicolumn{2}{|c|}{ 'Regalona Baer' } & \multicolumn{2}{|c|}{ 'Villarrica' } \\
\hline & Temuco & Vicuña & Temuco & Vicuña \\
\hline Grain yield ${ }^{1}, \mathrm{t} \mathrm{ha}^{-1}$ & $1.8 \pm 1.78 \mathrm{~b}$ & $6.0 \pm 2.8 \mathrm{a}$ & $0.9 \pm 0.56 \mathrm{~B}$ & $6.0 \pm 1.3 \mathrm{~A}$ \\
\hline Seed diameter ${ }^{1}, \mathrm{~mm}$ & $2.05 \pm 0.10 \mathrm{a}$ & $2.07 \pm 0.15 \mathrm{a}$ & $2.22 \pm 0.17 \mathrm{~A}$ & $1.96 \pm 0.12 \mathrm{~B}$ \\
\hline 1000 seed weight ${ }^{1}, \mathrm{~g}$ & $3.08 \pm 0.08 \mathrm{a}$ & $2.94 \pm 0.07 b$ & $3.29 \pm 0.08 \mathrm{~A}$ & $2.47 \pm 0.17 \mathrm{~B}$ \\
\hline \multicolumn{5}{|l|}{ Proximal analysis, $\mathrm{g} \mathrm{kg}^{-1} \mathrm{DM}$} \\
\hline Moisture & $113.4 \pm 0.5 \mathrm{a}$ & $65.6 \pm 1.2 \mathrm{~b}$ & $122.6 \pm 0.8 \mathrm{~A}$ & $68.7 \pm 1.2 \mathrm{~B}$ \\
\hline Ash & $34.5 \pm 1.3 b$ & $42.2 \pm 2.8 \mathrm{a}$ & $33.1 \pm 0.6 \mathrm{~B}$ & $48.9 \pm 6.8 \mathrm{~A}$ \\
\hline Protein $(\mathrm{N} \times 6.25)$ & $181.8 \pm 1.0 \mathrm{a}$ & $190.0 \pm 8.4 \mathrm{a}$ & $196.8 \pm 7.3 \mathrm{~A}$ & $183.0 \pm 4.9 \mathrm{~A}$ \\
\hline Fat & $46.0 \pm 1.3 b$ & $56.5 \pm 1.3 \mathrm{a}$ & $29.7 \pm 0.2 \mathrm{~B}$ & $46.5 \pm 5.0 \mathrm{~A}$ \\
\hline Crude fiber & $21.2 \pm 1.6 \mathrm{a}$ & $21.1 \pm 0.4 \mathrm{a}$ & $57.0 \pm 3.1 \mathrm{~A}$ & $43.5 \pm 3.7 \mathrm{~A}$ \\
\hline Total carbohydrates & $603.0 \pm 2.7 b$ & $624.7 \pm 9.9 \mathrm{a}$ & $560.8 \pm 7.3 B$ & $610.4 \pm 5.3 \mathrm{~A}$ \\
\hline Sucrose & $22.6 \pm 3.0 \mathrm{a}$ & $22.8 \pm 3.9 \mathrm{a}$ & $19.0 \pm 1.9 \mathrm{~B}$ & $24.1 \pm 3.3 \mathrm{~A}$ \\
\hline Glucose & $1.1 \pm 0.1 \mathrm{~b}$ & $2.4 \pm 0.04 \mathrm{a}$ & $1.2 \pm 0.09 \mathrm{~B}$ & $2.2 \pm 0.15 \mathrm{~A}$ \\
\hline Raffinose & $2.5 \pm 0.3 \mathrm{a}$ & $2.6 \pm 0.20 \mathrm{a}$ & $2.7 \pm 0.2 \mathrm{~B}$ & $3.1 \pm 0.08 \mathrm{~A}$ \\
\hline \multicolumn{5}{|l|}{ Dietary fiber, $\mathrm{g} \mathrm{kg}^{-1} \mathrm{DM}$} \\
\hline TDF & $115.9 \pm 23.9 \mathrm{a}$ & $116.1 \pm 1.6 \mathrm{a}$ & $125.2 \pm 2.8 \mathrm{~A}$ & $150.7 \pm 20.0 \mathrm{~A}$ \\
\hline IDF & $112.3 \pm 23.8 \mathrm{a}$ & $99.3 \pm 2.1 \mathrm{a}$ & $121.2 \pm 5.9 \mathrm{~A}$ & $121.8 \pm 22.1 \mathrm{~A}$ \\
\hline SDF & $3.6 \pm 0.1 b$ & $16.8 \pm 0.4 \mathrm{a}$ & $4.0 \pm 3.2 \mathrm{~B}$ & $28.9 \pm 2.1 \mathrm{~A}$ \\
\hline \multicolumn{5}{|l|}{ Minerals, mg $100 \mathrm{~g}^{-1} \mathrm{DM}$} \\
\hline $\mathrm{Ca}$ & $110.77 \pm 3.02 b$ & $278.39 \pm 7.32 \mathrm{a}$ & $212.90 \pm 11.65 \mathrm{~B}$ & $301.95 \pm 29.46 \mathrm{~A}$ \\
\hline $\mathrm{Mg}$ & $175.34 \pm 0.40 \mathrm{a}$ & $164.82 \pm 1.18 b$ & $176.77 \pm 0.37 \mathrm{~A}$ & $168.18 \pm 0.46 \mathrm{~B}$ \\
\hline $\mathrm{Na}$ & $11.33 \pm 12.82 \mathrm{a}$ & $<0.01 \pm-$ & $10.60 \pm 5.37 \mathrm{~A}$ & $<0.01 \pm-$ \\
\hline $\mathrm{K}$ & $2710.2 \pm 30.85 a$ & $1063.82 \pm 60.81 b$ & $2688.04 \pm 26.78 \mathrm{~A}$ & $1209.78 \pm 23.52 B$ \\
\hline $\mathrm{Fe}$ & $7.80 \pm 0.45 b$ & $25.51 \pm 1.50 \mathrm{a}$ & $5.72 \pm 0.73 \mathrm{~B}$ & $34.23 \pm 0.37 \mathrm{~A}$ \\
\hline $\mathrm{Cu}$ & $1.74 \pm 0.08 b$ & $2.47 \pm 0.09 \mathrm{a}$ & $1.58 \pm 0.08 \mathrm{~B}$ & $2.49 \pm 0.11 \mathrm{~A}$ \\
\hline $\mathrm{Mn}$ & $4.47 \pm 0.06 \mathrm{a}$ & $4.11 \pm 0.18 b$ & $2.38 \pm 0.01 \mathrm{~B}$ & $4.33 \pm 0.06 \mathrm{~A}$ \\
\hline $\mathrm{Zn}$ & $7.67 \pm 0.02 b$ & $9.56 \pm 0.09 \mathrm{a}$ & $8.47 \pm 0.22 \mathrm{~B}$ & $9.20 \pm 0.04 \mathrm{~A}$ \\
\hline $\mathrm{P}$ & $367.38 \pm 0.87 b$ & $416.78 \pm 15.23 \mathrm{a}$ & $288.81 \pm 10.00 \mathrm{~B}$ & $460.21 \pm 18.98 \mathrm{~A}$ \\
\hline \multicolumn{5}{|l|}{ Vitamins, mg $100 \mathrm{~g}^{-1} \mathrm{DM}$} \\
\hline Vitamin $B_{1}$ & $0.63 \pm 0.01 b$ & $0.83 \pm 0.006 \mathrm{a}$ & $0.35 \pm 0.008 \mathrm{~B}$ & $0.53 \pm 0.007 \mathrm{~A}$ \\
\hline Vitamin $B_{2}$ & $0.06 \pm 0.003 b$ & $0.07 \pm 0.003 \mathrm{a}$ & $0.07 \pm 0.002 \mathrm{~A}$ & $0.09 \pm 0.005 \mathrm{~A}$ \\
\hline Vitamin $B_{3}$ & $1.52 \pm 0.01 b$ & $2.44 \pm 0.005 a$ & $1.39 \pm 0.002 \mathrm{~B}$ & $2.26 \pm 0.04 \mathrm{~A}$ \\
\hline Vitamin C & $22.39 \pm 0.01 b$ & $31.22 \pm 4.20 \mathrm{a}$ & $49.30 \pm 5.36 \mathrm{~A}$ & $26.49 \pm 4.17 \mathrm{~B}$ \\
\hline Saponins, mg $100 \mathrm{~g}^{-1} \mathrm{DM}$ & $2.20 \pm 0.20 b$ & $3.22 \pm 0.38 \mathrm{a}$ & $2.38 \pm 0.49 \mathrm{~A}$ & $2.11 \pm 0.39 \mathrm{~A}$ \\
\hline $\mathrm{a}_{\mathrm{w}}$ & $0.55 \pm 0.01 \mathrm{a}$ & $0.33 \pm 0.002 b$ & $0.57 \pm 0.005 \mathrm{~A}$ & $0.33 \pm 0.001 \mathrm{~B}$ \\
\hline $\mathrm{pH}$ & $6.24 \pm 0.06 \mathrm{a}$ & $6.27 \pm 0.06 \mathrm{a}$ & $6.16 \pm 0.006 \mathrm{~A}$ & $6.233 \pm 0.06 \mathrm{~A}$ \\
\hline Acidity, $\mathrm{g} \mathrm{H}_{2} \mathrm{SO}_{4} 100 \mathrm{wb}^{-1}$ & $0.36 \pm 0.03 a$ & $0.21 \pm 0.016 b$ & $0.26 \pm 0.02 B$ & $0.34 \pm 0.03 \mathrm{~A}$ \\
\hline TPC, mg AG $100 \mathrm{~g}^{-1} \mathrm{DM}$ & $12.39 \pm 1.84 \mathrm{a}$ & $19.20 \pm 5.48 \mathrm{a}$ & $22.87 \pm 2.93 \mathrm{~B}$ & $31.92 \pm 1.14 \mathrm{~A}$ \\
\hline DPPH, \% inhibition & $60.81 \pm 2.40 \mathrm{a}$ & $59.01 \pm 0.96 \mathrm{a}$ & $41.71 \pm 4.77 \mathrm{~B}$ & $73.14 \pm 3.20 \mathrm{~A}$ \\
\hline
\end{tabular}

All data are the means \pm SD of three replicates. Lowercase and uppercase letters are used to compare Regalona Baer and Villarrica genotypes at Temuco and Vicuña localities, respectively. Means in the same row followed by same letter type are not significantly different $(\mathrm{P}<0.05)$.

TDF: total dietary fiber; IDF: insoluble dietary fiber; SDF: soluble dietary fiber; $\mathrm{a}_{\mathrm{w}}$ : water activity; TPC: total phenolic compounds; DPPH: free radical scavenging activity. ${ }^{1}$ Data are means \pm SD of 15 replicates. 
differences $(\mathrm{P}<0.05)$, with a range between 65.6-122.6 $\mathrm{g}$ $\mathrm{kg}^{-1} \mathrm{DM}$ (Table 3). The higher relative humidity at the much rainier locality of Temuco explains such differences with respect to seeds harvested at Vicuña (Table 1). Moisture values from the drier locality were similar to those found by Torrez et al. (2002), in a range between 73.4-127.4 g $\mathrm{kg}^{-1} \mathrm{DM}$ for highland varieties of quinoa assessed at the marginal high desert conditions in Bolivia. On the other hand, the values in the seed at Temuco were similar to the $120 \pm 0.4 \mathrm{~g} \mathrm{~kg}^{-1}$ DM reported by Chauhan et al. (1992), for quinoa seeds obtained under cold climate conditions in Canada $\left(50^{\circ} 40^{\prime} \mathrm{N}\right.$ lat, $556 \mathrm{~m}$ a.s.1.). In this context significant differences $(\mathrm{P}<0.05)$ were also observed for water activity $\left(a_{w}\right)$ between localities (Table 3 ) with the lowest values on seeds harvested at arid Vicuña locality. The $\mathrm{pH}$ did not differ between genotypes assessed, as it did the acidity content.

Ash and fat contents were also significantly affected by location (Table 3). The general variation for ash content between genotypes and localities ranged from 33.1 to 48.9 $\mathrm{g} \mathrm{kg}^{-1} \mathrm{DM}$, with higher values registered at Vicuña locality for both genotypes. Thus, the ash values found in our study correlated well with the ash content of quinoa seeds obtained under salinity conditions $\left(0-500 \mathrm{~mol} \mathrm{NaCl} \mathrm{m}{ }^{-3}\right)$ with values between 5.5-53.8 $\mathrm{g} \mathrm{kg}^{-1} \mathrm{DM}$ (Koyro and Eisa, 2008). Averaged over two locations, the maximum mean value for fat content was observed in 'Regalona Baer' harvested at Vicuña $\left(56.5 \pm 1.3 \mathrm{~g} \mathrm{~kg}^{-1} \mathrm{DM}\right)$. In general, the observed fat contents were also in good agreement with data given by other authors under similar environmental conditions (Torrez et al., 2002; Repo-Carrasco-Valencia and Serna, 2011).

Interestingly, the ANOVA for two quinoa genotypes revealed no significant differences $(\mathrm{P}<0.05)$ for seed protein content between localities in a range from 181.8 to $196.8 \mathrm{~g} \mathrm{~kg}^{-1} \mathrm{DM}$ (Table 3). These results demonstrate the great adaptability of quinoa to differing agro-climatic conditions, representing a tremendous potential for diversification of agricultural systems in places where production constraints and environmental changes affect the access to protein rich diet (Bhargava et al., 2007). Thus, the seed protein content reported in our study was higher than those reported by Miranda et al. (2012) (128.5$\left.161.0 \mathrm{~g} \mathrm{~kg}^{-1} \mathrm{DM}\right)$, Repo-Carrasco-Valencia and Serna (2011) (139.6-154.7 $\left.\mathrm{g} \mathrm{kg}^{-1} \mathrm{DM}\right)$ and by Gonzalez et al. (2011) (91.5-155.3 $\left.\mathrm{g} \mathrm{kg}^{-1} \mathrm{DM}\right)$. Nevertheless, Bhargava et al. (2007) reported seed protein contents among various Andean genotypes between 12.55-21.02\%, which were more similar to our findings.

Crude fiber did not change significantly for the two quinoa genotypes between localities $(\mathrm{P}<0.05)$. However, 'Villarrica' showed higher content for Temuco and Vicuña localities with 57.0 and $43.5 \mathrm{~g} \mathrm{~kg}^{-1} \mathrm{DM}$, respectively. These results were higher than those reported by RepoCarrasco-Valencia and Serna (2011), with values of 26.0 $\mathrm{g} \mathrm{kg}^{-1} \mathrm{DM}$; even much higher than wheat, corn, sorghum
(Sorghum bicolor L.), common rye (Secale cereale L.), and triticale (Triticale hexaploide Lart.) (Repo-Carrasco et al., 2003), representing in addition a good source of fiber among grains.

Total carbohydrate was the most abundant component in quinoa seeds, ranging 560.8 to $624.7 \mathrm{~g} \mathrm{~kg}^{-1} \mathrm{DM}$. Among its components, sucrose was higher than glucose and raffinose in all experimental genotypes (Table 3 ). The sugars content reported in this study, with the exception of raffinose, were similar to those reported by Miranda et al. (2010), in quinoa seeds obtained in Elqui Valley (coastal zone near to Vicuña). Glucose and total carbohydrate content were significantly $(\mathrm{P}<0.05)$ increased in both genotypes at the arid environment. On the other hand, 'Regalona Baer' and 'Villarrica' showed an increase of glucose in its grains when the two genotypes were grown in the arid environment, meanwhile raffinose was increased only in 'Villarrica' genotype $(\mathrm{P}<0.05)$. Studies on salinized and non-salinized quinoa plants growing under greenhouse conditions found that sugars in quinoa seeds is decreased notably in presence of salinity over 300 mol $\mathrm{NaCl} \mathrm{m}{ }^{-3}$, whereas lower concentrations of $\mathrm{NaCl}(<$ $300 \mathrm{~mol} \mathrm{~m}^{-3}$ ) influenced positively the sugars content in comparison with no-salinized treatment (Koyro and Eisa, 2008). This findings match well even with previous reports in cereal crops, where long term carbohydrate storage occurs during reproductive development as enhanced in response to the variety of environmental stresses (Gill et al., 2001).

Total dietary (TDF), insoluble (IDF), and soluble fiber (SDF) contents of quinoa genotypes at the two localities are summarized in Table 3. Significant differences $(\mathrm{P}<$ $0.05)$ were observed in SDF values for the two quinoa genotypes, which were higher under arid conditions, whereas TDF and IDF did not differ $(\mathrm{P}<0.05)$ between genotypes at the two localities. The TDF values registered in our study were similar to those reported by RepoCarrasco-Valencia and Serna (2011) in a range between 135 and $159 \mathrm{~g} \mathrm{~kg}^{-1} \mathrm{DM}$. Additionally, these results were even higher than those reported in rice and similar to barley (Yalçın et al., 2007), showing the potential of quinoa for its use not only as a nutritional supplement but also as a functional food ingredient in developing novel foods. Likewise, IDF values were similar to those reported by Repo-Carrasco-Valencia and Serna (2011), ranging between 119 and $143 \mathrm{~g} \mathrm{~kg}^{-1} \mathrm{DM}$. So far, there are few studies reporting information of dietary fiber in quinoa, however there is no studies analyzing the effect of genotype-environment interaction on TDF, IDF, and SDF contents. In spite of the lack of information, it is possible to find in cereal and legume grains crops, non-related and strong positive/negative genotype-environment effects on the dietary fiber content (Yalçın et al., 2007; StoughtonEns et al., 2010).

Seed mineral components assessed in the two quinoa genotypes registered significant differences $(\mathrm{P}<0.05)$, 
when these were grown either at the cold region of Temuco or at the arid location of Vicuña. The results indicated that $\mathrm{K}$ was the most abundant among minerals on quinoa seeds, with higher content $(\mathrm{P}<0.05)$ in the two genotypes under environmental conditions of Temuco. Likewise, the contents of $\mathrm{Mg}$ and $\mathrm{Na}$ in both genotypes were also higher at Temuco, despite Temuco soils registered lower content of $\mathrm{Mg}$ and $\mathrm{Na}$ exchangeable than Vicuña soils (Table 2). On the other hand, $\mathrm{P}, \mathrm{Ca}, \mathrm{Fe}, \mathrm{Cu}$, and $\mathrm{Zn}$ content were higher $(\mathrm{P}<0.05)$ in the two genotypes at the arid locality of Vicuña (Table 3), despite Fe soil values were lower in this locality. Finally, the Mn content in 'Regalona Baer' presented a higher content $(\mathrm{P}<0.05)$ at Temuco locality, whereas the content in 'Villarrica' genotype was higher ( $\mathrm{P}$ $<0.05)$ at the arid location of Vicuña. In general the seed mineral content obtained in our study was similar to other studies conducted previously by Chauhan et al. (1992), Torrez et al. (2002), and Karyotis et al. (2003). The higher seed-ash content at Vicuña (Table 3) matches well with the overall higher soluble minerals content reported for such soils, excepting for $\mathrm{Na}$ that was higher at Vicuña but much less accumulated in seeds. These results confirm the action of a selective mechanism to control the minerals distribution in quinoa seeds, suggesting a highly protected seed interior leading to high salinity resistance of quinoa seeds during germination, as suggested by Koyro and Eisa (2008).

Vitamin contents (B1, B2, B3, and C) in the two genotypes grown at two localities varied significantly $(\mathrm{P}<0.05)$ (Table 2). In this regard, thiamine (B1) content ranged between $0.35-0.83 \mathrm{mg} 100 \mathrm{~g}^{-1} \mathrm{DM}$, with the highest content in 'Regalona Baer' harvested at the arid Vicuña locality. These results were similar to those described by Jancurová et al. (2009), with mean values of $0.38 \mathrm{mg} 100 \mathrm{~g}^{-1}$ DM. B2 vitamin content in our

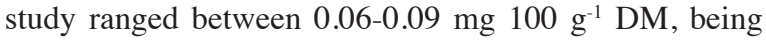
substantially lower than those reported in quinoa by Ruales and Nair (1993), in a range of 0.20-0.39 mg 100 $\mathrm{g}^{-1} \mathrm{DM}$. and similar to those described by Shewry et al. (2011), in a range between 0.0857-0.1071 mg $100 \mathrm{~g}^{-1} \mathrm{DM}$, for winter wheat varieties assessed in a multi environment assay in Europe. On the other hand, B3 vitamin ranged between 1.39 and $2.44 \mathrm{mg} 100 \mathrm{~g}^{-1} \mathrm{DM}$ with a significant low content in Temuco locality $(\mathrm{P}<0.05)$ in the two quinoa genotypes. This could be associated to the effect of contrasting environmental conditions between the two localities, such as has been suggested by Shewry et al. (2011) in winter wheat. Finally, vitamin C content for the two genotypes presented significant differences $(\mathrm{P}<0.05)$ between localities with opposite effects. Thus, vitamin C was higher for 'Villarrica' at Temuco locality (49.30 $\left.\pm 5.36 \mathrm{mg}^{\mathrm{AA}} 100 \mathrm{~g}^{-1} \mathrm{DM}\right)$, whereas the high content for 'Regalona Baer' was obtained at the arid Vicuña locality (22.39 $\pm 0.01 \mathrm{mg}$ AA $\left.100 \mathrm{~g}^{-1} \mathrm{DM}\right)$. Interestingly, all vitamin $\mathrm{C}$ contents found in our study were higher than previous reports on quinoa and other Andean grains, confirming quinoa as good source of vitamins, especially vitamin B complex and vitamin C (Ruales and Nair, 1993; Jancurová et al., 2009).

Saponins content, a bitter-tasting set of terpenoids, located in the outer layers of the seed coat, was affected by cultivation location only for 'Regalona Baer' $(\mathrm{P}<0.05)$; no significant differences were found for 'Villarrica'. Values obtained in this study ranged between $2.11 \pm 0.39$ and $3.22 \pm 0.38 \mathrm{mg} 100 \mathrm{~g}^{-1} \mathrm{DM}$ (Table 3), which were similar to those reported by Chauhan et al. (1992) and higher than lowland/coastal genotypes grown at central region in Chile $\left(34^{\circ} \mathrm{S}\right.$ lat), in a range between 0.2-1.5 mg $100 \mathrm{~g}^{-1}$ DM by Martinez et al. (2009). It has been described that variation of saponins content in quinoa depends strongly on the genotype (Jancurová et al., 2009; Martínez et al., 2009). So, its content is higher in bitterflavor genotypes than in sweet, or low-saponins varieties, in a range between 0.1 and $5 \mathrm{mg} 100 \mathrm{~g}^{-1} \mathrm{DM}$ (Jancurová et al., 2009).

The concentrations of total phenolic compounds found in our study are summarized in Table 3. It was possible to observe in both quinoa genotypes higher values at the arid Vicuña locality than at experimental cold-temperate region, in a range 12.39-31.92 $\mathrm{mg}$ GA $100 \mathrm{~g}^{-1} \mathrm{DM}$. Thus, our results were similar to values reported in quinoa grown under similar climatic condition in Chile by Miranda et al. (2010) with mean value of $28.41 \mathrm{mg} \mathrm{GA}$ $100 \mathrm{~g}^{-1} \mathrm{DM}$. Phenolic compounds are the most important class of secondary metabolites in plants playing a variety of roles in response to changing environmental conditions and in overcoming stress constraints (Wahid et al., 2007). Furthermore, these phytochemicals compounds have gained increased interest due to their antioxidative, cardiovascular protective, anti-allergic, antiinflammatory, antiviral, and anti-carcinogenic activities (Dini et al., 2010). Based in the above information, quinoa could be considered as a potentially valuable new crop source of phenolic compounds, even much better that common cereals and legumes grains (Djordjevic et al., 2010).

Antioxidant activities, as a percentage of radical scavenging activity of DPPH (extracts with concentration of $1.5 \mathrm{mg} \mathrm{mL}^{-1}$ ), are shown in Table 3. There was no significant difference between localities in free radical scavenging activities in 'Regalona Baer' $(\mathrm{P}<0.05)$. However, 'Villarrica' had the highest percentage of radical scavenging activities $(71.14 \%)$ in seeds harvested at the arid Vicuña locality $(\mathrm{P}<0.05)$; with a much higher total phenolic content. So, this association may even be incorporated in breeding programs, leading to use the total phenolic content as a reliable parameter to select quinoa genotypes with increased functional properties. Our results concerning the quinoa antioxidant activity were similar to that reported by Nsimba et al. (2008), which obtained in two quinoa genotypes mean values of $72.1 \%$ of radical scavenging activities for Bolivian 
genotype and 59.2\% for Japan sea-level type, suggesting in that case that non-phenolic compounds might also play an important role in the free radicals scavenging activity.

The standardized trait data of all variables assessed in our study were represented in a biplot for finding a lower-dimensional pattern from high-dimensional data set (Figure 1). The first two principal components of the analysis explained $82.9 \%$ of the total variation of the variable-standardized data. It was possible to observe in the biplot that cold-temperate and arid environments were distributed on the left and right side from the central axis of PC1, respectively. Thus, the environment-induced relationship among variables and genotypes matched well in each quadrant of biplot, describing positive correlation when vectors from the origin to each variable marker (white circle) presented an acute angle, and a negative correlation when this was obtuse. In this context, 'Villarrica' at coldtemperate climate had positively correlated the following variables: seed diameter, protein, vitamin $\mathrm{C}$, insoluble dietary fiber, crude fiber, and $\mathrm{Mg}$ content; whereas 'Regalona Baer' at the same locality had correlated: 1000 seed weight, acidity, moisture, water activity, $\mathrm{Na}$, and $\mathrm{K}$ content. At the arid Vicuña locality, 'Villarrica' registered positively correlated: total phenolic compounds, vitamin B2, vitamin B3, total and soluble dietary fiber, glucose, raffinose, ash, $\mathrm{Ca}, \mathrm{Zn}, \mathrm{Fe}$, and $\mathrm{Cu}$ content, meanwhile 'Regalona Baer': saponins, DPPH, total carbohydrates, sucrose, vitamin $\mathrm{B} 1$, lipids, $\mathrm{pH}, \mathrm{P}$, and $\mathrm{Mn}$ content. It could be noted that biplot analysis established that coldtemperate climate condition in the two quinoa genotypes affected positively a better behavior of seed traits (size and weight components) and the content of protein, vitamin C, and crude fiber, as well as sodium content. Likewise, under arid climate conditions the biplot analysis showed that quinoa seeds presented a better content of phenolic compounds, minerals, carbohydrates, saponins, and vitamin B complex. In addition, this environmental condition also established a negative correlation with seed size and weight components, matching well with the relationship of seeds component when quinoa plants are grown under stressing conditions (Koyro and Eisa, 2008). In this sense, the analysis performed in our study provides useful information for planning genetic and productive improvements in quinoa focused in its nutritional and functional properties in different environments.

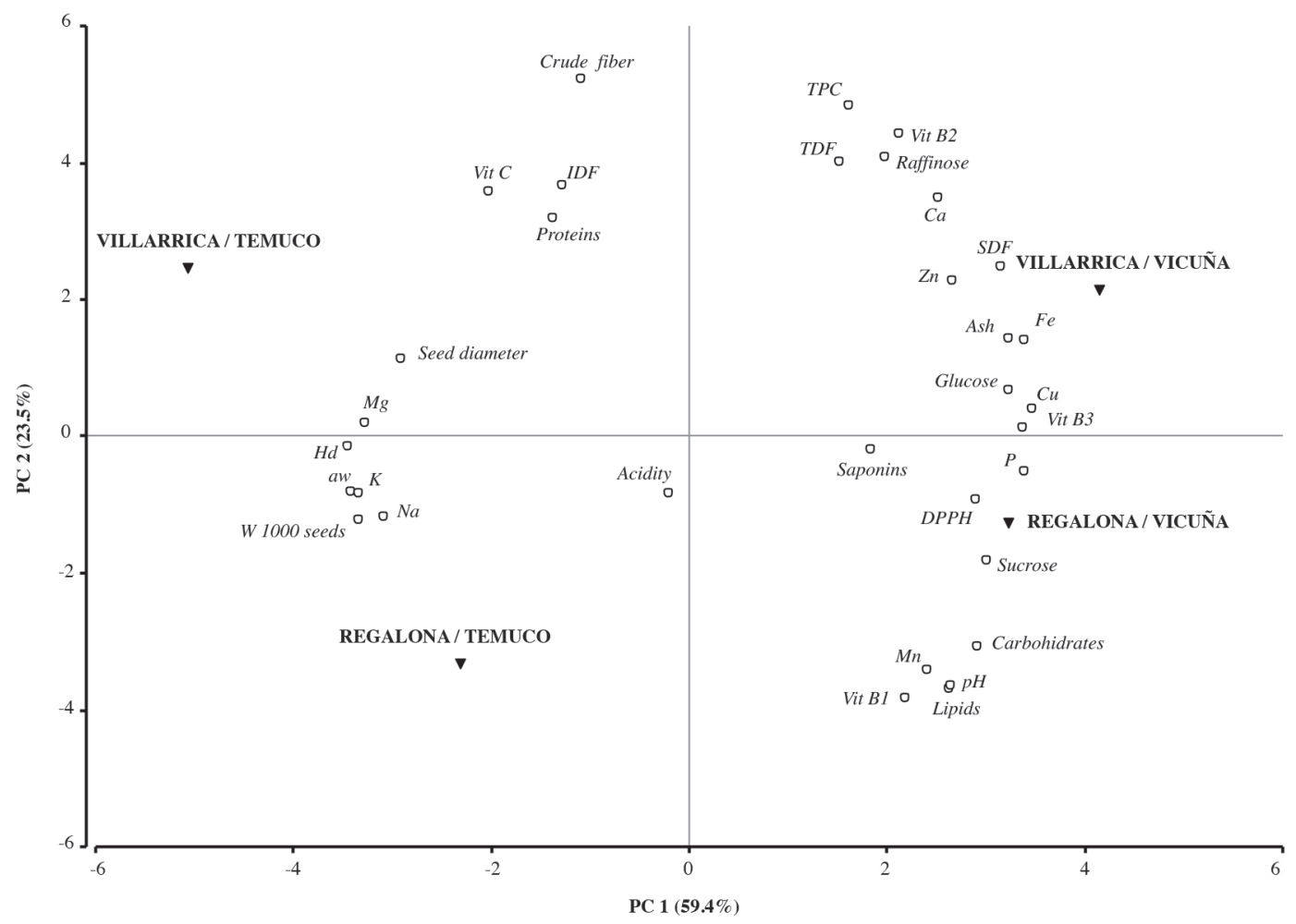

TDF: total dietary fiber; IDF: insoluble dietary fiber; SDF: soluble dietary fiber; $\mathrm{a}_{\mathrm{w}}$ : water activity; Hd: moisture; TPC: total phenolic compounds; DPPH: free radical scavenging activity.

Figure 1. Principal component analysis (PCA) biplot of quinoa seed components (white circle) from two genotypes grown at Temuco and Vicuña localities (black triangle). Cold-temperate and arid environments are represented on the left and right side from the central axis of PC1, respectively. 
Nevertheless, further studies should be conducted to characterize the regulatory mechanism involved in grainfilling under contrasting environment conditions.

\section{CONCLUSIONS}

Contrasting environment conditions (climate and soil characteristics) in our study affected significantly grain yield and seed composition in lowland/coastal quinoas. The much more stressing climatic conditions at the arid location of Vicuña in Chile influenced positively upon carbohydrates, fat, ash, soluble dietary fiber, vitamins B, saponins, and phenolic compounds content in both Regalona Baer and Villarrica genotypes. The protein content was not affected by environment in both genotypes; however, its content was higher than that of most traditional cereals. The present study addresses for the first time the nutritional variability in lowland/ coastal quinoas as affected by genetic background versus the effects of environmental changes, demonstrating that quinoa from Southern Chile can be expanded to new agro-ecological sites, particularly where more stressful environments are predominant.

\section{ACKNOWLEDGEMENTS}

Funding was provided by grant FONDECYT 1100638, Chile.

\section{LITERATURE CITED}

AOAC. 1995. Official method of analysis. $16^{\text {th }}$ ed. Association of Official Analytical Chemists (AOAC), Washington, D.C., USA.

Aranda, M., M. Vega, and F. Villegas. 2005. Routine method for quantification of starch by planar chromatography (HPTLC). Journal of Planar Chromatography 18:285-289.

Barakat, M.Z., M.F.A. El-Wahab, and M.M. El-Sadr. 1955. Action of N-bromosuccinimide on ascorbic acid. Analytical Chemistry 27:536-540.

Bhargava, A., S. Shukla, and D. Ohri. 2007. Genetic variability and interrelationship among various morphological and quality traits in quinoa (Chenopodium quinoa Willd.) Field Crops Research 101:104-116.

Chauhan, G.S., N.A.M. Eskin, and R. Tkachuk. 1992. Nutrients and antinutrients in quinoa seed. Cereal Chemistry 69:85-88.

Chuah, A.M., Y-C. Lee, T. Yamaguchi, H. Takamura, L-J. Yin, and T. Matoba. 2008. Effect of cooking on the antioxidant properties of coloured peppers. Food Chemistry 111:20-28.

Dini, I., G.C. Tenore, and A. Dini. 2010. Antioxidant compound contents and antioxidant activity before and after cooking in sweet and bitter Chenopodium quinoa seeds. LWT-Food Science and Technology 43:447-451.

Djordjevic, T.M., S.S. Šiler-Marinkovic, and S.I. DimitrijevicBrankovic. 2010. Antioxidant activity and total phenolic content in some cereals and legumes. International Journal of Food Properties 14:175-184.

Fuentes, F.F., D. Bazile, A. Bhargava, and E.A. Martínez. 2012. Implications of farmers' seed exchanges for on-farm conservation of quinoa, as revealed by its genetic diversity in Chile. Journal of Agricultural Science 150:702-716. doi:10.1017/ S0021859612000056.
Gill, P.K., A.D. Sharma, P. Singh, and S.S. Bhullar. 2001. Effect of various abiotic stresses on the growth, soluble sugars and water relations of sorghum seedlings grown in light and darkness. Bulgarian Journal of Plant Physiology 27:72-84.

Gonzalez, J.A., Y. Konishi, M. Bruno, M. Valoy, F.E. Prado. 2011. Interrelationships among seed yield, total protein and amino acid composition of ten quinoa (Chenopodium quinoa) cultivars from two different agroecological regions. Journal of Agricultural and Food Chemistry 92:1222-1229.

Hair, J.F., R.E. Anderson, R.L. Tatham, and W.C. Black. 1992. Multivariate data analysis. Macmillan Publishing Company, New York, USA.

Infostat. 2008. InfoStat, Versión 2008. Grupo InfoStat, Facultad de Ciencias Agrarias, Universidad Nacional de Córdoba, Córdoba, Argentina.

Jancurová, M., L. Minarovičová, and A. Dandár. 2009. Quinoa - a Review. Czech Journal of Food Sciences 27:71-79.

Karyotis, Th., C. Iliadis, Ch. Noulas, and Th. Mitsubonas. 2003. Preliminary research on seed production and nutrient content for certain quinoa varieties in a saline-sodic soil. Journal of Agronomy and Crop Science 189:402-408.

Koyro, H.W., and S.S. Eisa. 2008. Effect of salinity on composition, viability and germination of seeds of Chenopodium quinoa Willd. Plant and Soil 302:79-90.

Martínez, E.A., E. Veas, C. Jorquera, R. San Martín, and P. Jara. 2009. Re-Introduction of quinoa into arid Chile: cultivation of two low landraces under extremely low irrigation. Journal of Agronomy and Crop Science 195:1-10.

Miranda, M., A. Vega-Galvez, J. Lopez, G. Parada, M. Sanders, M. Aranda, et al. 2010. Impact of air-drying temperature on nutritional properties, total phenolic content and antioxidant capacity of quinoa seeds (Chenopodium quinoa Willd.) Industrial Crops and Products 32:258-263.

Miranda, M., A. Vega-Gálvez, I. Quispe-Fuentes, M.J. Rodríguez, H. Maureira, and E.A. Martínez. 2012. Nutritional aspects of six quinoa (Chenopodium quinoa Willd.) ecotypes from three geographical areas of Chile. Chilean Journal of Agricultural Research 72:175-181.

Nsimba, R.Y., H. Kikuzaki, and Y. Konishi. 2008. Antioxidant activity of various extracts and fractions of Chenopodium quinoa and Amaranthus spp. seeds. Food Chemistry 106:760-766.

Patzsch, K., S. Netz, and W. Funk. 1988. Quantitative HPTLC of sugars part 1: Separation and derivatization. Journal of Planar Chromatography 1:39-45.

Repo-Carrasco, R., C. Espinoza, and S.E. Jacobsen. 2003. Nutritional value and use of the Andean crops quinoa (Chenopodium quinoa) and kañiwa (Chenopodium pallidicaule). Food Reviews International 19:179-189.

Repo-Carrasco-Valencia, R.A.-M., and L.A. Serna. 2011. Quinoa (Chenopodium quinoa Willd.) as a source of dietary fiber and other functional components. Ciência e Tecnologia de Alimentos 31:225-230.

Ruales, J., and B.M. Nair. 1993. Contents of fat, vitamins and minerals in quinoa (Chenopodium quinoa Willd.) seeds. Food Chemistry 48:131-137.

San Martín, R., and R. Briones. 2000. Quality control of commercial quillaja (Quillaja saponaria Molina) extracts by reverse phase HPLC. Journal of Agricultural and Food Chemistry 80:2063-2068.

SAG. 2012. División Semillas: Lista de variedades protegidas especies agrícolas. Servicio Agrícola y Ganadero (SAG), Santiago, Chile. Available at http://www.sag.gob.cl/sites/ default/files/registro_de_variedades_protegidad_de_especies_ agricolas_30-11-2012.pdf (accessed 10 January 2013).

Shewry, P.R., F. Van Schaik, C. Ravel, G. Charmet, M. Rakszegi, Z. Bedo, and J.L. Ward. 2011. Genotype and environment effects on the contents of vitamins B1, B2, B3, and B6 in wheat grain. Journal of Agricultural and Food Chemistry 59:10564-10571.

Stoughton-Ens, M.D., D.W. Hatcher, N. Wang, and T.D. Warkentin. 2010. Influence of genotype and environment on the dietary fiber content of field pea (Pisum sativum L.) grown in Canada. Food Research International 43:547-552. 
Torrez, M.O., A.A. Guzmán, and R. Carvajal 2002. Valoración nutricional de 10 variedades de quinua (Chenopodium quinoa Willd.) del altiplano boliviano. BIOFARBO 10:55-60.

United Nations. 2011. Draft resolution II, International Year of Quinoa, 2013. Agriculture development and food security, Report of the Second Committee. A/RES/66/446. 21 p. Available at http://www.un.org/ga/search/view_doc.asp?symbol=A/66/446 (accessed February 2012).

Vega-Gálvez, A., M. Miranda, J. Vergara, E. Uribe, L. Puente, and E.A. Martínez. 2010. Nutrition facts and functional potential of quinoa (Chenopodium quinoa Willd.), an ancient Andean grain: A review. Journal of the Science of Food and Agriculture 90:25412547.
Wahid, A., S. Gelani, M. Ashraf, and M.R. Foolad. 2007. Heat tolerance in plants: An overview. Environmental and Experimental Botany 61:199-223.

Yalçın, E., S. Celik, T. Akar, I. Sayim, and H. Koksel. 2007. Effects of genotype and environment on b-glucan and dietary fiber contents of hull-less barleys grown in Turkey. Food Chemistry 101:171-176. 